\title{
N.F.S. Grundtvig and Nationalism in Wales
}

\author{
By A.M. Allchin
}

The pressures of change in the twentieth century are felt in different ways in different countries. In England the fact that our national language has become an international lingua franca has made us particularly vulnerable to the threat of an anonymous international, commercial culture, which in so far as it has any roots has them in North America, but which has its influence everywhere in the English-speaking world and beyond. In this situation some of the poets and writers, and some of the historians of Britain and Ireland have become particularly conscious of the value of local loyalties and of the importance of what is small, rooted, and parochial. Like Patrick Kavanagh, the Irish poet of the middle of this century, they have tried explicitly to rescue the word parochia from its implications of narrowness and lack of vision, and have sought to remind us that each place has its own potential of life.

I make these preliminary remarks because I wish at the outset to salute the great work of Anders Pontoppidan Thyssen on the parochial histories of the diocese of Haderslev. This work seems to me to be at once the product of a scientific historian who knows the value of the careful painstaking assemblage of facts, but also the work of a man of faith who knows that a parish centres on a church building, and that building holds within itself the secret of values not to be measured solely in terms of this world, the memories of many generations and the presence of the Word of God.

The purpose of this article is to examine one particular facet of the influence of Grundtvig in the history of Britain during this century. As is well known, Grundtvig has been little enough studied in Britain, outside the circle of educationalists, and even there knowledge of the folk high schools has often been superficial. But in the smallest of the three nations of Britain, the situation is interestingly different. In the development of Welsh nationalism during the last sixty to seventy years Grundtvig's influence has been a factor of at least some importance. 
For Grundtvig, as indeed for most of the inhabitants of our island, there is no doubt that Britain meant primarily England. That is not altogether surprising. The English are by far the largest national group in Great Britain; 45 million as compared with five million in Scotland and less that three million in Wales. But Grundtvig was not unaware of the existence of other peoples and languages in the British Isles. In the second part of his Haandbog $i$ Verdenshistorien he notes that though the Welsh lost their independence at the end of the thirteenth century yet still in the nineteenth century they preserve their own Tunge-maal og Bogsprog. This fact in itself made him think that there must have been more substance to the Welsh nation than one would gather from the accounts of Gildas and Bede which recount the AngloSaxon conquest of the island. ${ }^{1}$

The persistent vitality of the Welsh language, both in its spoken and its written form, which Grundtvig observed with a certain surprise in the 1830 s is still a fact to be reckoned with in the 1990s. Despite the serious decline in the number of Welsh speakers during this century the language has shown in the last twenty years remarkable capacities of adaptation and recovery. It has also produced throughout this century very fine writers both in prose and in verse, outstanding among them John Saunders Lewis (1893-1985).

Saunders Lewis was not only the founder and first president of the Welsh National Party, Plaid Cymru, but also a distinguished literary critic and historian. In the latter part of his life he became a highly accomplished dramatist. We now have four volumes of his plays in English translation made by the American scholar Joseph Clancy, thus making them much more accessible to us. I turn to a play first produced on television in 1962 called Excelsior. The play, whose plot need not detain us, is a political satire, so successful as satire that immediately after its production its author was threatened with a libel action by an offended Labour M.P. What concerns us is the way in which one of the leading characters, at the beginning of the play a highly idealistic young Presbyterian minister called Chris, refers to Grundtvig. 
"Can you, Chris ... awaken the nation?« his girlfriend, Dot, asks him.

"There is no nation. It is necessary to create it, to recreate it. That's our purpose, Dot, that's our call. It's part of our faith. That's the next revival.«

»It isn't too late? « the young lady replies.

Chris responds, "Have you ever heard of Grundtvig?«

She replies, »Grundtvig? ... From Denmark wasn't he? «

»Yes, « replies the young man. »One of the happiest countries in Europe today. But when Grundtvig was a young man Denmark was as miserable and lethargic and unsure of itself as Welsh-speaking Wales is today. Grundtvig created a Danish nationalist movement, through people's schools, by teaching the common people their ancient history, their ancient songs, by resurrecting a love of country that had died.«

"Just as you said at the meeting, " replies the adoring young woman.

"Grundtvig was a minister too. I would like to be a Grundtvig for Wales. Stand against the tide and save our nation. $\ll^{2}$

Now I must not give the impression that everyone in Welsh Wales knows even that much about Grundtvig. In the next act, Dot's father, the M.P., who though still a Welsh-speaking Welshman has been thoroughly Anglicized by his years in the House of Commons, responds to the word Grundtvig just as your average Englishman would have done at that time. »Grundtvig ... wait now. Yes, tape-recorders and electronics, quite a good company, last year's profits the highest ever. But it is necessary to be careful in putting money into electronics... « I have to explain that in England in the 1960s and '70s the Grundig Company was the best-known supplier of electronic equipment. If one tried to explain Grundtvig's name in England one was constantly reduced to referring to tape-recorders: »Grundig with TV in the middle«.

Now this solitary, but rather striking reference to Grundtvig in one of Saunders Lewis' plays alerts us to the fact that at least in parts of Welsh-speaking Wales, Grundtvig's name is known and admired in a way which is not the case in England. It may be 
interesting to explore a little more why this should be so. How is it that Saunders Lewis, who I do not think ever visited Scandinavia, should refer to Grundtvig this way?

The origins of the Welsh Nationalist Party can be traced to a meeting which took place in Pwllheli, North Wales, in August 1925 in which two very small groups of men, one from the south, the other from the north, agreed to unite to form a new political party. ${ }^{3}$ None of those involved had any political experience. Most were teachers, academics, or ministers. The impractical nature of their movement at the beginning is shown by the fact that they made the first public statement of their aims and objectives in a small Breton periodical, which I suppose had a circulation of between ten and twenty in Wales! In its early years the Welsh Nationalist Party had more the nature of a cultural than a political movement. For most of those involved in it the question of the Welsh language was far and away the most important issue. But among its earliest members there was one man who had an experience of political life that none of his colleagues could equal. This was David James Davies and to him we must now turn.

D.J. Davies (1893-1956) was born in South Wales, the son of a coalminer. At the age of twelve he went to work in the coal mines in Glamorgan. In 1912 at the age of 19 he went to the U.S.A. and stayed there for more than ten years. During his years in America he not only worked underground as a miner for a time but also travelled widely, working with a party of mining prospectors and visiting most of the United States. At another period he supported himself for a time as a professional boxer. In the last years of the war he joined the Unites States Navy as a ship's engineer and again travelled widely. On his return to Wales after the war he returned to work in the pits but after an industrial accident, decided that at all costs he must get more education. This he began to do from 1924 onwards.

Thus it was in 1924, at the age of 31 , D.J. Davies first came to Denmark and this event proved a turning point in his life. In April of that year he went to the International Folk High-School at Helsingør. As we shall see he was decisively influenced by what he found there. There too he met a young Irish woman, Noelle French. Very soon they decided to get married. In the 
autumn of that year Davies came back to Denmark to the highschool at Vestbirk, at that time under the leadership of Grønvald Nielsen. Here he gained not only a great admiration for the methods of physical education but also the conviction that he should return to his own country and work for its freedom and development. In the summer of 1925 he and his fiancee got married, and in the autumn of that year he entered as a student at the University College of Aberystwyth. Eight years later in 1932 he had earned his doctorate in agricultural economics.

D.J. Davies was clearly a man of considerable ability and of great character, with a varied experience of life. In his American days he had worked for a time as a trades union organizer and been regarded by his employers as a dangerous agitator. Needless to say at this stage of his life he was a thoroughgoing Marxist. It was the experience in Denmark which more than anything else altered his attitude towards political and economic affairs, and indeed to life in general.

I quote now from an essay on his life written and published in Welsh in 1977.

His visits to Denmark made a deep impression on his thinking, and through him on the nationalist movement in Wales. He went there, as we have seen, as a fervent socialist, believing in the class war, in Marxist materialism, and in the common ownership or nationalization of property and the means of production. But in Denmark he came in contact with a very different economic philosophy, that of cooperation, based not on conflict between social classes, but on harmony between them, and on awaking in people the desire to work for the common good. He learned that it is necessary to create a special type of person if cooperation is to succeed, by giving young people a truly national education, an education which will create a deep love for their country and which will inspire all classes in society to work together. From this time onwards he believed unshakably that cooperation was the one economic system which could assure that every group in society was truly free and equal; the only system which would de-proletarianize the workers by giving them real property and a share of 
control in industry. He came to see the value of private property as an essential element in the development of personality, giving people full responsibility for themselves and developing self-respect and self-confidence and all the other qualities which form a mature personality. He con. sidered that it is not possible to base cooperation on materialism, but rather on spiritual and religious values; because cooperation demands readiness on the part of individuals to work together voluntarily to serve the common good and to make sacrifices on its behalf. ${ }^{4}$

During the 1930s Davies became the chief, indeed the only economist of standing in the Welsh National Party and his influence was considerable. His views on cooperation and decentralization came to be adopted as the official policy of the party. Saunders Lewis acknowledged his indebtedness both to his practical knowledge of political life and to his understanding of economic theory. Lewis himself was a convert to Roman Catholicism and was deeply influenced by the social teaching of the Roman Catholic church, in particular by the philosophy of Jacques Maritain. In an interesting way he and D.J. Davies were able to find common ground in their convictions about the importance of decentralization and of the urgent need to make cooperation the founding principle of their economic plans. Both could affirm Saunders Lewis' vision of the nation as a community of communities. "A nation's civilization is rich and complex simply because it is a community of communities, and for that reason also the freedom of the individual is a feasible proposition ... his liberty depends on his being not a member of one association but of many. « Both also were firmly convinced that Welsh nationalism had to be resolutely European and internationalist. Both looked beyond England, in the one case to Scandinavia and in the other to France, to see the European context for the independent Welsh state which they dreamed of creating.

It was of great importance in the early years of Welsh nationalism that both men in their different ways should have stressed the international character of their nationalist convictions. This European attitude has marked the Welsh Nationalist 
Party ever since, even though this fact has been little recognized by the major political parties in Britain, which have continued to attack Plaid Cymru for being narrow and parochial in its viewpoint. It is such attitudes which have created at the present time not only in Wales but in Scotland and Ireland the hope that the development of the European Community after 1992 may help to change and improve the relations between the four nations which make up Britain and Ireland.

Undoubtedly within the Welsh Nationalist Movement, D.J. Davies' ideas were of the greatest importance. Another of the leading members of the party in this pioneering period, Wynne Samuel, wrote of him at the time of his death in 1956,

In Wales, he gave the study of economics a decisive historic turn, and for the first time in many centuries the study of Welsh economics became a practical Welsh reality. This was perhaps his greatest contribution not only to the nationalist movement but to the treatment of economics as an integral part of Welsh life. One must try to imagine the desultory condition of independent Welsh political economic thought thirty years ago to realize the great contribution Dr. D.J. Davies has made to Wales in this direction. ${ }^{5}$

What was the content of this Welsh economic thought? It was in the first place an attempt to think of Wales as an economic unit, not just as a marginal region of England, in which the south is an appendage of Bristol and the north of Liverpool. It was then an attempt to think of the economic structures appropriate to a small nation which in the 1930 s was being devastated by the recession and by a frightening level of unemployment. It was in this context that the key terms of D.J. Davies' economic thought became decentralization and cooperation.

Decentralization was a major theme in Davies' vision of the future. Democracy would be enhanced and costs cut by transferring powers to local government, while the decentralized control of industry in what would be anyway a small national community would provide individuals with a greater sense of self-esteem. »The closer the economic 
factor is brought to the individual, the more easily it can be controlled, a fact which explains the success of cooperation. There is a far greater stimulus to individual enterprise, interest, and cooperation in a small nation, in which each individual feels that he counts for something than in a large state in which the individual is lost in the mass. ${ }^{6}$

For D.J. Davies it was the sense of national identity which he believed would provide a social dynamic for the cooperative movement he envisaged.

Whereas cooperative systems might result from compulsion in state socialist and fascist systems they would develop voluntarily among people inspired by a sense of nationality. "A sense of nationality gives the individual a higher ideal and a wider loyalty, and at the same time is not too cold and abstract an ideal to guide and stimulate him in his daily work and contacts. « Davies refused to isolate the economic factors in society from a more general consideration of the nature of society as a whole. »Unemployment is not a separate problem to be solved independently of everything else, but part of the great problem of creating a united, organic, living society. To do this we need the necessary psychological stimulus to cooperation, which is given by the sense of national unity and the kinship of all classes in the nation. ${ }^{7}$

In all this Davies had the complete support of his wife Noelle. Indeed it was she who became the Grundtvig scholar, publishing in 1931 a brief but well balanced study of Grundtvig's life and thought under the title Education for Life, A Danish Pioneer. Her understanding of Grundtvig and his influence in Denmark is one which underlines the importance of the individual. She quotes Grundtvig's characterization of Holberg and applies it to himself, »Every mighty spirit unites within himself in the bond of individuality, all that is widely scattered in his time and people; and thus thou wert the true interpreter of thine own age and of thy northern land. But that which alone can create the union within itself, the unknown quantity upon the spirit's counting 
board, the vision of genius was thine own and God's. ${ }^{8}{ }^{8}$ It is a commentary on the state of Grundtvig studies in Britain that this small book published sixty years ago is still one of the best works on this subject that has been written in our country. In 1944 she published as a pamphlet for Plaid Cymru a briefer essay entitled Grundtvig of Denmark. Here she brought out more explicitly the nationalist elements in Grundtvig's thought. Against the darkness of the war years, she saw in Grundtvig's life a cause for hope. "The people of Wales, who have clung to their nationality through so many centuries of adversity, should be the last to doubt whether Grundtvig's faith in his people's future was justified. If one nation can achieve and hold fast a national spirit like that possessed by Grundtvig and imparted through his folk high schools, then no calamities in war, no corruption in peace, no centuries of subjugation can permanently overthrow it. $\ll^{9}$ Noelle Davies' interest in Grundtvig continued throughout her life. After her husband's death she returned to Ireland, but she remained actively associated with the work of the Grundtvig Selskabet and for many years provided the English summaries published in Grundtvig Studier.

Among the hopes of D.J. and Noelle Davies was that of establishing a folk high school in Wales. In 1933, they bought a large house in South Breconshire near the industrial valleys to be the centre for such a venture, and lived there for some years. Clearly they had in mind in particular the large numbers of unemployed in the industrial south Wales valleys of the time. It is interesting that D.J. seems to have had a particular fascination for the character of Kristen Kold. One gains the impression that he too, with his varied experience of life, with his years of experience as a professional boxer, would have had special gifts as a teacher of young people whose basic experience had been one of deprivation and poverty. But failure to secure financial support from the government and lack of adequate private financial backing doomed their project from the start. Ceinwen Thomas is surely right in judging this failure to have been a major tragedy in Welsh life during the period of the depression.

D.J. Davies was clearly a man of an expansive outgoing personality with a great gift for putting others at ease. »He was a lively and entertaining speaker, and his humour and his sense of 
the ridiculous made him very good company. Wherever he was the group around him would be marked by the sound of laughter and of non-stop discussion and exchange. ${ }^{10}$ In this he was the precise opposite of Saunders Lewis, who entirely lacked this capacity, and thus acquired a largely undeserved reputation for being aloof and unfriendly. D.J. Davies by contrast had a great fund of stories from his American days which had certainly grown in the telling. "He had travelled much in America and so was at home everywhere and with everyone, and he made a conscious effort to make other people feel at home with him. I remember once hearing from a friend of his about a coalminer coming for the first time to a Plaid Cymru summer school, at a time when the membership of the party was more academic than it is now. The miner felt like a fish out of water amongst all the teachers and preachers. But in the end he found another coalminer at the meeting and was quite at home with him. He never discovered that the other miner was Dr. D.J. Davies whose books he had been trying to read. « 11

Like many others in the twentieth century, D.J. Davies found it difficult to arrive at consistent position on questions of religious belief. Unsurprisingly he passed through a period of agnosticism as a young man, rebelling against the protestant nonconformity in which he grew up. To the end of his days he could be strongly critical of clerics and church establishments. But it is clear that at least from his visits to Denmark his sense of the importance of spiritual values in human and social life was restored; like many of his generation he retained a deep respect for the ethical teaching of Christianity. Intellectually he found himself drawn towards the Unitarians, a distinct but minority voice within the tradition of Welsh nonconformity since the seventeenth century; but while his head went with them, he found that his heart was still held by the hymns of the Methodist revival, the outspokenly incarnational and trinitarian hymns which have played a vital part in the life of Welsh-speaking Wales for the last two centuries. I imagine that one could find parallels for these unresolved inner tensions amongst folk high school people in twentieth century Denmark. 
In making any assessment of the influence of Grundtvig in twentieth century Wales we have to ask two questions. What was the influence of D.J. Davies on the first thirty years of Plaid Cymru? What has been the influence of Plaid Cymru in Wales in this century as a whole?

On the first question we can take the judgment of Gwynfor Evans, the greatest political figure in the Welsh Nationalist Movement in the last thirty years. Writing at the time of D.J. Davies' death he said, "When the history of the national movement is written, he will be seen as one of the three or four most powerful, formative influences in its growth.« Without question Saunders Lewis was the outstanding spokesman of the movement in the first twenty years of its life, but the distinct Roman Catholic flavour of his formulations of political, social and economic policy undoubtedly caused problems for a movement which was seeking to appeal to an audience overwhelmingly nonconformist and protestant in its religious views. It is I think highly probable that if the positions of D.J. and Noelle Davies had been more prominent in the councils of Plaid Cymru, they might have succeeded in formulating its policies in ways more acceptable to the Welsh electorate. As it is, D.J. Davies did succeed in giving Plaid Cymru a coherent, if not always practical, economic programme which was clearly distinct from those of the three major political parties active in Wales at the time, Conservative, Liberal, and Labour. It was due to him more than to anyone else that Plaid Cymru managed to evolve from being a largely cultural movement into a small but genuine political force. And as we have seen it was his meeting with Denmark and with the ideas of N.F.S. Grundtvig as he found them in the folk high schools of the 1920s which was of decisive significance in his own personal and intellectual development.

On the second question, what influence has Plaid Cymru had on the life of Wales as a whole? It is difficult for an outsider to judge. The Nationalist Party has never been more than a minority movement in Wales, and has never had any great influence in central government in London. The first nationalist M.P., Gwynfor Evans, was elected in 1967. Since then there has never been less than one or more than four Plaid Cymru M.P.s in the 
House of Commons. But this very slender representation at Westminster is not the whole of the story. For a variety of reasons, little by little in the last forty years, Welsh national institutions have been multiplying. Though there is no devolution of power from Westminster, there is a considerable devolution of administrative functions. More and more Welsh institutions of one kind or another have been formed, from the Tourist Board to the Trades Union Council to Welsh National Opera. A Welsh language television channel has been established. Though the number of Welsh speakers has continued to decline there has been some improvement in the legal status of the Welsh language and its place in the school system. The churches no longer have to bear the burden of being almost the only distinctive national institutions in Welsh public life; this is from the Welsh point of view a fortunate development since the influence of all the churches, and particularly the influence of the nonconformist denominations has declined sharply in the last forty years. Thus at a time when the sense of national identity in a small country like Wales has been under constant pressure from the growing international culture of the Anglo-American world, within Wales itself a number of developments have been taking place which have acted as at least partial counter-agents to this trend. Amongst these the influence of N.F.S. Grundtvig has been one significant if little noticed element.

\section{Noter}

1 N.F.S. Grundtvig. Udvalgte Skrifter, ed. Holger Begtrup, vol. VII, p.7.

2 The Plays of Saunders Lewis, vol.\#, translated by Joseph Clancy (Llandybie, 1985), p. 26.

3 For the early history of the Welsh Nationalist Party, see D. Hywel Davies, The Welsh Nationalist Party 1925-1945: A Call to Nationhood (Cardiff 1983).

4 »D.J. Davies« by Ceinwen H. Thomas, in Adnabod Deg, ed. Derec Llwyd Morgan (Cardiff 1977), pp. 148-9. 
6 D. Hywel Davies, p. 87.

7 Ibid., pp. 99-100.

8 Noelle Davies. Education for Life, A Danish Pioneer (London 1931), p. 20.

9 Quoted in D. Hywel Davies, p. 108.

10 Ceinwen H. Thomas, p. 144.

11 Ibid., p. 145. 